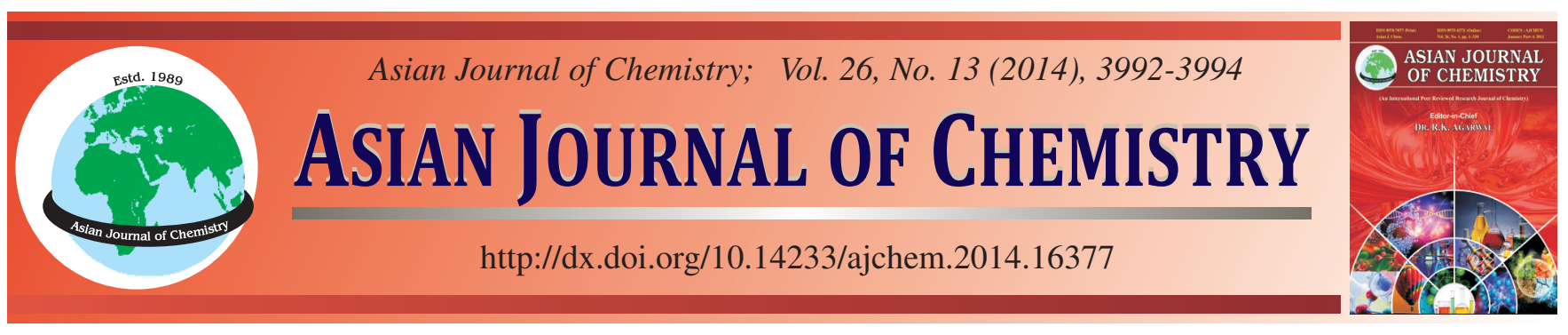

\title{
Synthesis, Spectral Studies and Antibacterial Activity of 3-(4-Phenyl-2,3-dihydro-1,5-benzodiazepin-2-yl)chromone
}

\author{
Vinay Prabha Sharma* and Praveen Kumar
}

Department of Chemistry, Meerut College, Meerut-250 001, India

*Corresponding author: E-mail: shambhavisharma98@hotmail.com

Received: 16 September 2013;

Accepted: 16 January 2014;

Published online: 23 June 2014;

AJC-15390

3-(4-Phenyl-2,3-dihydro-1,5-benzodiazepin-2-yl)chromone (PHBDC) has been synthesized by reacting 1-phenyl-3-(chromon-3-yl)-2propene-1-one (chalcone) with $o$-phenylenediamine. Structures of chalcone as well as PHBDC were established on the basis of elemental analysis, IR and PMR spectral studies. 3-(4-Phenyl-2,3-dihydro-1,5-benzodiazepin-2-yl)chromone has been found to be antibacterial against bacillus bacteria some of which cause food poisoning, anthrax (a malignant boil), etc.

Keywords: IR, PMR, Synthesis, Antibacterial, 3-(4-Phenyl-2,3-dihydro-1,5-benzodiazepin-2-yl)chromone.

\section{INTRODUCTION}

Chromones as well as 2,3-dihydro-1H-1,5-benzodiazepines are of immense biological importance. Chromones possess medicinal activities like antimicrobial ${ }^{1-4}$, antiinflammatory $^{5,6}$, diuretic ${ }^{7,8}$, coronary vasodialator ${ }^{9}$, antispasmodic ${ }^{10}$ and CNS-stimulant ${ }^{11}$. 2,3-Dihydro- $1 \mathrm{H}$-1,5-benzodiazepines and related systems exhibit, anticonvulsant, antianxiety, analgesic, sedative, antidepressant and hypnotic activities ${ }^{12,13}$ and are part of a number of drugs ${ }^{14}$. In the light of these observations it was thought worthwhile to synthesize compounds incorporating these moieties with a view to test anti bacterial activities in them and hence title compounds were synthesized (Scheme-I).

\section{EXPERIMENTAL}

All melting and boiling points are uncorrected. Infrared spectra were recorded on SPECTRUM BX SERIES in $\mathrm{KBr}$. Absorption frequency is recorded in $\mathrm{cm}^{-1}$. The PMR spectra were recorded in $\mathrm{CDCl}_{3}$ and /DMSO- $d_{6}$ at BRUKER AVANCE II 400 NMR SPECTROMETER. The chemical shifts are expressed in ppm units $(\boldsymbol{\delta})$ downfield from internal tetramethyl silane (TMS) standard. Solvents and starting materials were purified using standard procedures. The purity of compounds was regularsly checked on TLC-plates coated with silica gel.

Synthesis of 3-formylchromone (2): This compound was synthesized starting with $o$-hydroxyacetophenone, dimethylformamide (DMF) and phosphorus oxy chloride according to the procedure and conditions mentioned in the chemical literature $^{15}$.<smiles>CC(=O)c1ccccc1O</smiles>

(1) (2)<smiles>CC(C)(C)CC(C=O)c1coc2ccccc2c1=O</smiles><smiles>O=c1c(C2CC(c3ccccc3)=Nc3ccccc3N2)coc2ccccc12</smiles>

Scheme-I

Synthesis of 1-phenyl-3-(chromon-3-yl)-2-propene-1one (3): To a solution of 3 -formylchromone $(0.01 \mathrm{~mol})$ and acetophenone $(0.01 \mathrm{~mol})$ in $40 \mathrm{~mL}$ of ethanol was added $15 \mathrm{~mL}$ of $40 \% \mathrm{KOH}$ in portions with shaking and keeping the temperature of reaction mixture below $10{ }^{\circ} \mathrm{C}$. The flask was kept at room temperature for $48 \mathrm{~h}$ for the completion of reaction. Now reaction mixture was acidified with glacial acetic acid and poured on crushed ice. Solid thus obtained was filtered, washed with water and was crystallized from ethanol. 
IR ( $\mathrm{KBr}$, pellets, $\left.v_{\max }, \mathrm{cm}^{-1}\right): 3014$ (=C-H str, aromatic), $1645(\mathrm{C}=\mathrm{O}$ str of chromone and $-\mathrm{CH}=\mathrm{CH}-\mathrm{CO}-\mathrm{Ph}$ moieties $)$, 1603 (C=Cstr), 1220 (C-Ostr.) and 900 (=C-H def). PMR $\left(\mathrm{DMSO}-d_{6}\right) \delta: 7.48-7.63(6 \mathrm{H}, \mathrm{m}, 5$ protons of phenyl ring and $\mathrm{C}_{6}-\mathrm{H}$ of chromone), $7.68\left(1 \mathrm{H}, \mathrm{m}, \mathrm{C}_{8}-\mathrm{H}\right.$ of chromone), 7.76 $\left(2 \mathrm{H}, \mathrm{m}, \mathrm{C}_{7}-\mathrm{H}\right.$ of Chromone and $\mathrm{C}_{3}-\mathrm{CH}=$ of propenone), 8.27 $\left(1 \mathrm{H}, \mathrm{d},=\mathrm{CH}-\mathrm{CO}\right.$ of propenone), $8.54\left(1 \mathrm{H}, \mathrm{dd}, \mathrm{C}_{5}-\mathrm{H}\right.$ of chromone) \& 8.59 ( $1 \mathrm{H}, \mathrm{s}, \mathrm{C}_{2}-\mathrm{H}$ of chromone).

Synthesis of 3-(4-phenyl-2,3-dihydro-1,5-benzodiazepin2-yl)chromone (4): To a solution of chalcone [3; $0.01 \mathrm{~mol}]$ in $40 \mathrm{~mL}$ of ethanol, solution of $o$-phenylenediamine $(0.012 \mathrm{~mol})$ in alcohol was added and refluxed for 6-7 h. The progress of reaction was monitored on TLC. After the completion of reaction, the reaction mixture was poured on crushed ice. The solid separated was filtered, washed with ethanol and recrystallized with $50 \%$ ethanol m.p. $240-41{ }^{\circ} \mathrm{C}$, yield $=70 \%$; Found $(\%)$ : $\mathrm{C}=78.69 ; \mathrm{H}=4.92 ; \mathrm{N}=7.65 ;$ calculated $(\%) \mathrm{C}=78.80 ; \mathrm{H}=$ $5.00 ; \mathrm{N}=7.96 \%$ ]; IR (KBr, pellets, $\left.v_{\max }, \mathrm{cm}^{-1}\right) ; 3295(\mathrm{~N}-\mathrm{H} \mathrm{str}$ of benzodiazepine ring), 3051 (=C-H str., Aromatic), 1618 ( $\mathrm{C}=\mathrm{O}$ str., chromone), 1532 ( $\mathrm{C}=\mathrm{N}$ str), 1321 (C-N str.), 1179 (C-O str). PMR $\left[\mathrm{CDCl}_{3}\right](\delta): 5.31$ [2H, d, $-\mathrm{CH}_{2}$ of 2,3 -dihydro 1,5-benzodiazepin ring]; 6.84-6.98 [4H, m, C-H of dihydrobenzodiazepin and three aromatic protons], 7.31-7.69 [10 $\mathrm{H}$, $\mathrm{m}, \mathrm{C}_{6}-\mathrm{H}, \mathrm{C}_{8}-\mathrm{H}, \mathrm{C}_{7}-\mathrm{H}, \mathrm{C}_{5}-\mathrm{H}$ of chromone and six other aromatic protons, $7.90\left[1 \mathrm{H}, \mathrm{S}, \mathrm{C}_{2}-\mathrm{H}\right.$ of chromone $]$ and $11.15[1 \mathrm{H}, \mathrm{S}, \mathrm{N}-$ $\mathrm{H}$ proton of dihydrobenzodiazepin moiety].

\section{RESULTS AND DISCUSSION}

Chalcones react with $o$-aminothiophenol to give benzoazepines $^{16}$. Therefore, it was thought that chalcones of chromones will react with bifunctional $o$-phenylenediamine to yield dihydrobenzodiazepinyl chromones (title compound). Motivated by this chalcone of chromone was condensed with $o$-phenylenediamine in ethanol by refluxing for $7 \mathrm{~h}$ to yield 3-(2,3-dihydro1,5-benzodiazepin-2-yl) chromone according to (Scheme-I). Chalcone (3) required for this purpose was prepared starting with $o$-hydroxyacetophenone (1). $o$-Hydroxy acetophenone was converted into 3 -formyl chromone (2) according to the procedure described in literature ${ }^{15}$. 3-Formyl chromone was condensed with acetophenone in ethanolic solution in presence of $10 \%$ aqueous solution of sodium hydroxide ${ }^{16}$.

Structures of chalcone, 1-phenyl-3-(chromon-3-yl)-2-propene1-one (3) and of title compound 3-(4-phenyl-2,3-dihydro-1,5benzodiazepin-2-yl) chromone were brought about on the basis of their elemental analysis, infrared spectrum as well as proton magnetic resonance spectrum.

Infrared spectrum of chalcone exhibited characteristic absorption band for $\mathrm{C}=\mathrm{O}$ stretching of chromone nucleus \& $\alpha, \beta$-unsaturated carbonyl moiety as a broad band around 1645 $\mathrm{cm}^{-1}$. Other usual bands were also present in this spectrum. But, IR-spectrum gave no direct evidence for the formation of chalcone. However, PMR-spectrum of the compound $\mathbf{3}$ completely revealed the structure of chalcone (3).

PMR-spectrum (in DMSO- $d_{6}$ ) of $\mathbf{3}$ showed signals in five groups for all twelve protons. Starting from highest field $\mathrm{C}_{6-}$ $\mathrm{H}$ of chromone \& 5 aromatic protons appeared as multiplet from $\delta 7.48$ to $7.63 . \mathrm{C}_{8}$ - $\mathrm{H}$ of chromone was visible at $\delta 7.68$. Third signal $(\delta 7.76)$ was a two proton multiplet which could be assigned to $\mathrm{C}_{7}-\mathrm{H}$ of chromone and $\mathrm{CH}=\mathrm{C}$ group proton directly attached to $\mathrm{C}_{3}$ of chromone. Doublet at $\delta 8.23$ can be assigned to $=\mathrm{CH}-\mathrm{CO}$ - proton of $-\mathrm{CH}=\mathrm{CH}-\mathrm{C}-$ moiety of chalcone which appeared downfield because of deshielding effect of $\mathrm{C}=\mathrm{O}$ group in neighbourhood. Signal visible at $\delta$ 8.54 may be assigned to $\mathrm{C}_{5}-\mathrm{H}$ of chromone and last signal, a singlet at $\delta 8.59$ in probably due to $\mathrm{C}_{2}-\mathrm{H}$ of chromone.

Infrared spectrum of $\mathbf{4}$, the title compound indicated the condensation of chalcone with $o$-phenylenediamine, because the broad absorption band at $1645 \mathrm{~cm}^{-1}$ got shifted to $\mathrm{C}=\mathrm{O}$ stretching of chromone only which was visible at $1618 \mathrm{~cm}^{-1}$. IR-spectrum was devoid of $2-\mathrm{NH}_{2}$ coupled vibrations and only $1-\mathrm{N}-\mathrm{H}$ stretching band was present at $3295 \mathrm{~cm}^{-1}$. Therefore, - $\mathrm{CH}=\mathrm{CH}-\mathrm{CO}$ - moiety has condensed with $o$-phenylenediamine to give 2,3-dihydro-1,5-benzodiazepin ring that contains 1-NH group. Other usual bands for the system viz. aromatic $=\mathrm{C}-\mathrm{H}$ stretching, $\mathrm{C}=\mathrm{C}$ and $\mathrm{C}=\mathrm{N}$ stretching, $\mathrm{C}-\mathrm{N}$ stretching and $\mathrm{C}-\mathrm{O}$ stretching were present in spectrum at $3051,1603,1532,1321$ and $1179 \mathrm{~cm}^{-1}$, respectively $=\mathrm{C}-\mathrm{H}$ Bending was visible at $900 \mathrm{~cm}^{-1}$.

PMR-spectrum of this compound $\mathbf{4}$ showed its formation. In PMR spectrum $\left(\mathrm{CDCl}_{3}\right)$ eighteen protons showed up in 5 groups. Starting from highest field first to appear were $-\mathrm{CH}_{2}$ protons of 2,3-dihydro-1,5-benzodiazepin moiety as a signal located at $\delta$ 5.31. $\mathrm{C}_{2}-\mathrm{H}$ of 2,3-dihydro-1,5-benzodiazepine and there aromatic protons appeared in the region $\delta 6.84-6.98$ as a multiplet. Third signal was ten proton multiplet in the region $\delta$ 7.31-7.69 which may be accounted to $\mathrm{C}_{6}-\mathrm{H}, \mathrm{C}_{8}-\mathrm{H}, \mathrm{C}_{7}-\mathrm{H}$ and $\mathrm{C}_{5}-\mathrm{H}$ of chromone ring and six other aromatic protons present in two aromatic rings. Singlet at $\delta 7.90$ may be ascribed to $\mathrm{C}_{2}-\mathrm{H}$ of chromone and last signal present at $\delta 11.75$ may be assigned to $-\mathrm{NH}$ proton.

A probable mechanism for the formation of present compound from chalcone is given in Scheme-II.<smiles>Nc1ccccc1NCC(=O)c1ccccc1</smiles><smiles>CN(C)C(=Cc1coc2ccccc2c1=O)COCCO</smiles><smiles>Cc1coc2ccccc2c1=O</smiles><smiles>O=c1c(C2CC(c3ccccc3)=Nc3ccccc3N2)coc2ccccc12</smiles>

Scheme-II 
Compound $\mathbf{4}$ was screened for antibacterial activity against Bacillus bacteria. It showed $100 \%$ inhibition of growth at $1 \%$ concentration $(\mathrm{w} / \mathrm{v})$ in $\mathrm{DMF}$.

\section{REFERENCES}

1. (a) V.P. Sharma, P. Kumar and M. Sharma, Asian J. Chem., 23, 4616 (2011); (b) V. B. Halnor, N. R. Dalvi, N. S. Joshi, C. H. Gill and B.K. Karale, Indian J. Chem., 45 B, 288 (2006).

2. R. Purnik, Y. Jay Prakesh Rao and G.J. Kurupadam, Indian J. Chem., 41B, 869 (2002).

3. S.M. Bhalekar and H.M. Prab, Indian J. Heterocycl. Chem., 17, 285 (2008).

4. M. Yamada and K. Koyama, Japan Kokai Tokyo Koha Jp, 07,165,748 (1995); Chem. Abstr., 124, 7336a (1996).

5. V. Gupta and U. Mishra, Indian J. Heterocycl. Chem., 17, 281 (2008).

6. R.G. Naik, S.L. Kattige, S.A.V. Bhat, B. Alreja, N.J. Desouza and R.H. Rupp, Tetrahedron Lett., 44, 2081 (1988).
7. C. P. Garg, V. P. Sharma and R.P. Kapoor, Indian J. Chem., 24B, 1197 (1985).

8. C.P. Garg, V.P. Sharma, V. Chhabra and R.P. Kapoor, Indian J. Chem., 27B, 469 (1988)

9. G.S. Barsoum and M.R. Kenawy, Am. Heart, 47, 297 (1954);.

10. E. Kohlstaedt and K.H. Klinger, Ger. Patent, 1,018,874; Chem. Abstr., 54, 5700 (1960).

11. D. Molho, E. Boschetti and L. Fontiane, Fr. M. 2472; Chem. Abstr, 61, 11975 (1964)

12. R.I. Fryer, Bicyclic Diazapines in Chemistry of Heterocyclic Compounds, 50, E. Taylor, Ed. Wiley (1992), Chapter II, Chem. Abstr., 73, $100054 \mathrm{w}(1970)$

13. L.H. Sternbach, J. Med. Chem., 22, 1 (1979).

14. T.L. Gilchrist, Heterocyclic Chemistry, John Wiley \& Sons Inc., New York, p. 346 (1991).

15. A. Nohara, T. Umetani and Y. Sanno, Tetrahedron, 30, 3553 (1974).

16. A.G. Nikalje, R.D. Ingle, V.E. Bhingolikar and R.A. Mane, Indian J. Heterocycl. Chem., 13, 37 (2003). 